\title{
THE ROLE OF ATTRACTION, ACCESSIBILITY, AMENITIES, AND ANCILLARY ON VISITOR SATISFACTION AND VISITOR ATTITUDINAL LOYALTY OF GILI KETAPANG BEACH
}

\author{
Taufiq Ismail \& Fatchur Rohman
}

Fakultas Ekonomi dan Bisnis, Universitas Brawijaya

E-mail: taufiq.ismail@ub.ac.id

\begin{abstract}
The 4A tourism components, including attraction, accessibility, amenities, and ancillary, become prominent variables to be explored for their impact on visitor satisfaction and attitudinal loyalty mainly for relatively new tourism destination. This research conducted at Gili Ketapang Beach located at Probolinggo Regency as this new destination got more attention among tourists in Indonesia. Direct survey and online survey were done to collect the data from the destination spot, which gained 41 useable questionnaires. Due to sample size constraint, this research uses Partial Least Square to analyze the relationship among variables. The finding confirms that only attraction and ancillary that significantly influences visitor satisfaction; while accessibility and amenities do not have a significant role in visitor satisfaction. Next, attitudinal loyalty influenced by attraction, ancillary, and facilities but not availability. Satisfaction indeed affects visitor attitudinal loyalty of Gili Ketapang Beach. Further, the mediation role of satisfaction is well proven to amplify the role of 4A tourism components, except for accessibility.
\end{abstract}

Keywords: attraction, accessibility, amenities, ancillary, satisfaction, attitudinal loyalty JEL Classification: M300

\begin{abstract}
ABSTRAK
Komponen pariwisata 4A yang terdiri dari daya tarik, aksesibilitas, fasilitas, dan tambahan menjadi variabel yang menarik untuk dieksplorasi dampaknya terhadap kepuasan pengunjung dan loyalitas atitudinal terutama untuk tujuan wisata yang relatif baru. Penelitian ini dilakukan di Pantai Gili Ketapang yang terletak di Kabupaten Probolinggo karena lokasi wisata yang baru ini semakin menarik perhatian para wisatawan di Indonesia. Survei langsung dan survei online dilakukan untuk mengumpulkan data dari tempat tujuan. Survei ini memperoleh 41 kuesioner yang bisa digunakan untuk mengolah data. Karena keterbatasan jumlah sampel, penelitian ini menggunakan Partial Least Square untuk menganalisis hubungan antar variabel. Temuan ini menegaskan bahwa hanya atraksi dan tambahan yang secara signifikan mempengaruhi kepuasan pengunjung; sementara aksesibilitas dan fasilitasnya tidak memiliki peran signifikan pada kepuasan pengunjung. Selanjutnya, loyalitas sikap dipengaruhi oleh ketertarikan, tambahan, dan fasilitas tetapi tidak dipengaruhi oleh aksesibilitas. Kepuasan memang mempengaruhi loyalitas sikap pengunjung Pantai Gili Ketapang. Selanjutnya, peran mediasi kepuasan terbukti dengan baik untuk memperkuat peran komponen pariwisata 4A, kecuali aksesibilitas.
\end{abstract}

Kata kunci: daya tarik, aksesibilitas, fasilitas, tambahan, kepuasan, loyalitas sikap Klasifikasi JEL: M300 


\section{Jurnal Manajemen Teori dan Terapan \\ Tahun 12. No. 2, Agustus 2019}

\section{INTRODUCTION}

Several researchers confirmed that tourism becomes one of the pivotal points that encourage welfare growth at least for the surrounding society at particular tourism destination (Song at al., 2012; Tugcu, 2014; Webster \& Ivanov, 2014). Aiming to increase the welfare of a particular region, the growth of new tourism destination is initiated by local governments in Indonesia, particularly in East Java Province. However, the readiness of those new destinations may not satisfy tourists when they visit so that it can cause switching behavior or reduce the intention to revisit. The initial tool to review destination is $4 \mathrm{~A}$ tourism components that mainly to observe destination readiness as perceived from visitor's perspective (Andrianto \& Sugiyama, 2016; Dewi et al., 2017).

Many areas in East Java that have great potential for its natural attractions, one of which is in Probolinggo Regency which has many tourist destinations such as Bromo Tengger Semeru, Jolosutro Waterfall, and Gili Ketapang Beach. Particularly for the Gili Ketapang beach, this destination also offers natural beauty for snorkeling but the tourists should take a boat for 30 minutes before arriving at the snorkeling spot. However, the access is quite challenging for boat trip; yet, the visitors rate on this beach can be calculated and controlled to maintain cleanliness and preservation of nature.

Attractions, accessibility and amenities are important components in the development of tourism objects because the attractiveness of a tourist destination lies in these three components other than ancillary. A place can be developed into a tourism destination needs to fulfill 4 (four) tourism components called 4As, namely attractions, accessibility, amenities and ancillary (Andrianto \& Sugiama, 2016). The quality and variation of each component needs to meet adequate criteria, so that it can be a component in providing satisfaction to tourists (Sugiama, 2014). Leask (2016) stated that an attraction is the pivotal matters of the destination appeals and the driver to visit a destination. Further, Goeldner \& Ritchie (2009) mentioned that attractions are the fundamental reasons why prospective visitors choose one destination over another. Classified and categorized attractions differently, categorized attractions into five main groups: culture, natural, event, recreation and entertainment.

Customer satisfaction is considered an important matter for destination in all sectors including the tourism sector. Customer satisfaction can be determined from the overall feeling and attitude of a person to an item that has been purchased (Solomon, 2017). Therefore tourism must also prioritize how the feeling of satisfaction that tourists have is achieved, one of them is by making improvements at least on amenities and ancillary rather than merely focusing on attraction and accessibility. The 4A tourism components are rarely observed in the recent 


\section{Taufiq Ismail}

\section{Fatchur Rohman}

article for Indonesia context. In ensuring the sustainability and customer satisfaction, the development of Gili Ketapang applies the principles of attraction, accessibility, amenities and ancillary that can satisfy the expectation of its visitors. Thus, this research tried to explore the role of these components on visitor satisfaction for Gili Ketapang destination.

The concept of loyalty has been discussed in a wide array of contexts, such as hotel (Suhartanto et al., 2013), ferry travel (McMullan \& Gilmore, 2008), retail (Jensen, 2011; Martin et al., 2009), supermarket (Orel \& Kara, 2014), coffee outlets (Chen \& Hu, 2010), and fast-food industry (Etemad-Sajadi \& Rizzuto, 2013). This is the concept that underlies some important decisions for a company, including tourism business, to maintain the relationship between their customers and the company. To consider the import role of loyalty, this research takes this construct as the dependent variable for revealing what can influence attitudinal loyalty in tourism context.

Addressing these issues, this research aims to investigate the role of attractions, accessibility, amenities, and ancillary on the satisfaction and attitudinal loyalty of visitors on Gili Ketapang Beach in Probolinggo and to explore the influence of visitor satisfaction as the moderating variable on visitor attitudinal loyalty.

\section{LITERATURE REVIEW}

\section{Tourism Components as the Independent Variable (X)}

The components of tourism consist of attraction, accessibilities, amenities, and ancillary (Andrianto \& Sugiyama, 2016). Attraction is clearly used as a tool to develop destinations (Leask, 2016). Tourism attraction can be nature, unique culture, and specific attractions (Hiransomboon, 2017; Andrianto \& Sugiyama, 2016; Dewi et al., 2017). In addition, related to accessibility, it is the infrastructure including roads, bridges, bus station, railway station, and airports event the accessibility of the tourism spot are considered as necessary component to attract more tourists (Jamaludin \& Kadir, 2017).

The infrastructure has some functions to connect a place to another place. The existence of transportation infrastructure will affect the frequency to transport or moving from one place to another. Good infrastructure supports good perception on transportation service of a particular destination. Third, amenities include accommodation, restaurants, tourist information, and other supporting infrastructure (Dewi et al., 2017). Amenities play critical role in shaping overall satisfaction of a tourist when they have to deal with food and sleeping time though only temporary stay. The last is ancillary as researchers increasingly seek to understand and communicate the significant successful management practices used to forecast and contribute to effective business practice (Connell et al., 2014; Leask, 2016). 


\section{Jurnal Manajemen Teori dan Terapan \\ Tahun 12. No. 2, Agustus 2019}

A good relationship between local community and the management in building good tourism experience among visitors is needed for enhancing tourism satisfaction and loyalty. The existence of tourism institutions (ancillary) that manage all facilities and also develop tourism objects can radiate secure feeling (protected) for the tourists. Also, the convenience of a tourist attraction depends also on the policies and management of the local institution. These four components are further elaborated by other variables. Destination marketing managers should highly consider traveler loyalty as an important goal (WU, 2016); further, visitor loyalty remains as an indicator of successful destination management (Wu, 2016).

\section{Visitor Satisfaction as the Mediating Variable (Z)}

Moderating variable in this study is visitor satisfaction on Gili Ketapang tourism destination. Satisfaction is the feeling of being happy or disappointed when an individual compares the perceived performance of the product (or result) to his/her expectations (Kotler \& Keller, 2016). Customer satisfaction or dissatisfaction is the customer's response to the evaluation of discrepancies / disconfirmations felt between previous expectations (or other performance norms) and actual perceived product performance. Whereas according to Zeithaml et al. (2016) customer satisfaction is a post-purchase evaluation where the alternatives chosen at least give the same results or exceed customer expectations, while dissatisfaction arises if the results obtained do not meet customer expectations. Kotler and Keller (2016) explain that customer satisfaction is a customer perception that compares expectations after purchase with perception after purchase. Satisfaction is robust concept in enhancing behavioral loyalty. Yet, the role of the $4 \mathrm{~A}$ components should be elaborated first. This notion leads to the following hypotheses.

H1. Attraction has significant role on visitor satisfaction

H2. Accessibility has significant role on visitor satisfaction

H3. Amenities has significant role on visitor satisfaction

H4. Ancillary has significant role on visitor satisfaction

\section{Visitor Attitudinal Loyalty as the Dependent Variable ( $Y$ )}

The concept of loyalty has been discussed in a wide array of contexts, such as hotel (Suhartanto et al., 2013), ferry travel (McMullan \& Gilmore, 2008), retail (Jensen, 2011; Martin at al., 2009), supermarket (Orel \& Kara, 2014), coffee outlets (Chen \& Hu, 2010), and fast-food industry (Etemad-Sajadi \& Rizzuto, 2013). This is the concept that underlies some important decisions for a company, including tourism business, to maintain the relationship between their customers and the company. To consider the important role of loyalty, this research takes this construct as the dependent variable for revealing whether the $4 \mathrm{~A}$ tourism influence attitudinal loyalty. Thus the hypothesis development is stated below:

H5. Attraction has significant role on visitor attitudinal loyalty 


\section{Taufiq Ismail}

\section{Fatchur Rohman}

H6. Accessibility has significant role on visitor attitudinal loyalty

H7. Amenities has significant role on visitor attitudinal loyalty

H8. Ancillary has significant role on visitor attitudinal loyalty

Satisfaction becomes an essential predictor of loyalty (Hussein et al., 2015) that should be explored in this research to confirm the former finding. For further elaboration, visitor satisfaction also influences attitudinal loyalty which leads to the following hypothesis:

H9. Visitor satisfaction has significant role on visitor attitudinal loyalty

Next, to justify the model exploration, the mediation role of satisfaction on visitor attitudinal loyalty in this research is examined through the following hypothesis:

H10. Satisfaction has significant role in mediating the relationship between $4 \mathrm{~A}$ tourism components and visitor attitudinal loyalty.

\section{METHODS}

\section{Sampling and Respondent Characteristics}

Survey becomes the only tool to collect the data through questionnaire as the data collection instrument in this research. On-site survey was done to ensure that the collected data are completely first-hand as well as the data are kept to portray the recent condition of the visitors' perceptions. Further there are also online based data in google form that were distributed to social media link through the assistance of one of the Gili Ketapang tourist guides. The on-site survey and online respondents were 30 and 11 completed questionnaires respectively. The following table presents the demographic profile of the respondents.

\section{Table 1.}

Profile of the Respondents

\begin{tabular}{ccc}
\hline Variables & & Percentage \\
\hline \multirow{2}{*}{ Gender } & Male & 76 \\
& Female & 24 \\
Age & 18 up to 27 & 85 \\
& 28 up to 37 & 15 \\
Education & Senior High School & 83 \\
& Undergraduate & 12 \\
Occupation & Others & 5 \\
& Student & 61 \\
& Government Officer & 5 \\
& Private Sector & 34 \\
City of Origin & Surabaya & 62 \\
& Malang & 22 \\
& Pasuruan & 2 \\
& Lumajang & 2 \\
& Lombok & 2 \\
Frequency of Visit & Kediri & 10 \\
& 1 & 88 \\
& $2-4$ & 5 \\
& $5-6$ & 0 \\
\hline
\end{tabular}


Mostly, the respondents are male with 18 to 27 years old of age range. The education background shows that 83 percent of the respondents are senior high school graduates. Further, most of them are students who came from Surabaya and took their first visit at Gili Ketapang. This research initial survey revealed that most of the respondents were indeed first time visitor of Gili Ketapang beach.

\section{Data Analysis}

This research utilized Partial Least Square (PLS) using SmartPLS software to analyze the data and test the hypotheses. When perception-based with Likert scale data are vulnerable for its normal distribution issues, PLS overcomes this problem since it is a variance based analysis (Hussein et al., 2015). Further, PLS is highly reliable for small size of sample since this research can only involve 41 respondents due to field data collection constraint. The steps of analysis follow the rule of thumbs on PLS analysis that run outer model for ensuring validity and reliability of research instrument and inner model for evaluating convergent and discriminant validity as well as multidimensionality tests.

Hussein (2015) stated that testing the hypothesis can be seen from the value of t-statistics and probability values. To test the hypothesis using statistical values, for alpha $5 \%$ the $t$ statistical value used is 1.96. So that the acceptance / rejection criteria of the hypothesis are $\mathrm{Ha}$ accepted and $\mathrm{HO}$ rejected when t-statistics is greater than 1.96. To reject / accept the hypothesis using probability then $\mathrm{Ha}$ is accepted if the value of $\mathrm{p}$ is less than 0.05 .

Whereas when the results of testing on the inner model are significant, it can be interpreted that there is a significant effect of latent variables on other latent variables. While testing the mediation hypothesis or indirect influence is done by a procedure developed by Sobel or known as the Sobel test (Ghozali \& Latan, 2014) using web-based Sobel calculator. This test is conducted in order to find out the significance value of indirect effects between variables, provided that the value of $\mathrm{t}$-value $>1.96$.

\section{RESULTS AND DISCUSSION}

\section{Outer Model Evaluation}

This research model consists of six constructs namely attraction, accessibility, amenities, ancillary, visitor satisfaction, and visitor attitudinal loyalty. Evaluating the validity and reliability of a construct is done by evaluating the measurement model. 


\section{Taufiq Ismail}

\section{Fatchur Rohman}

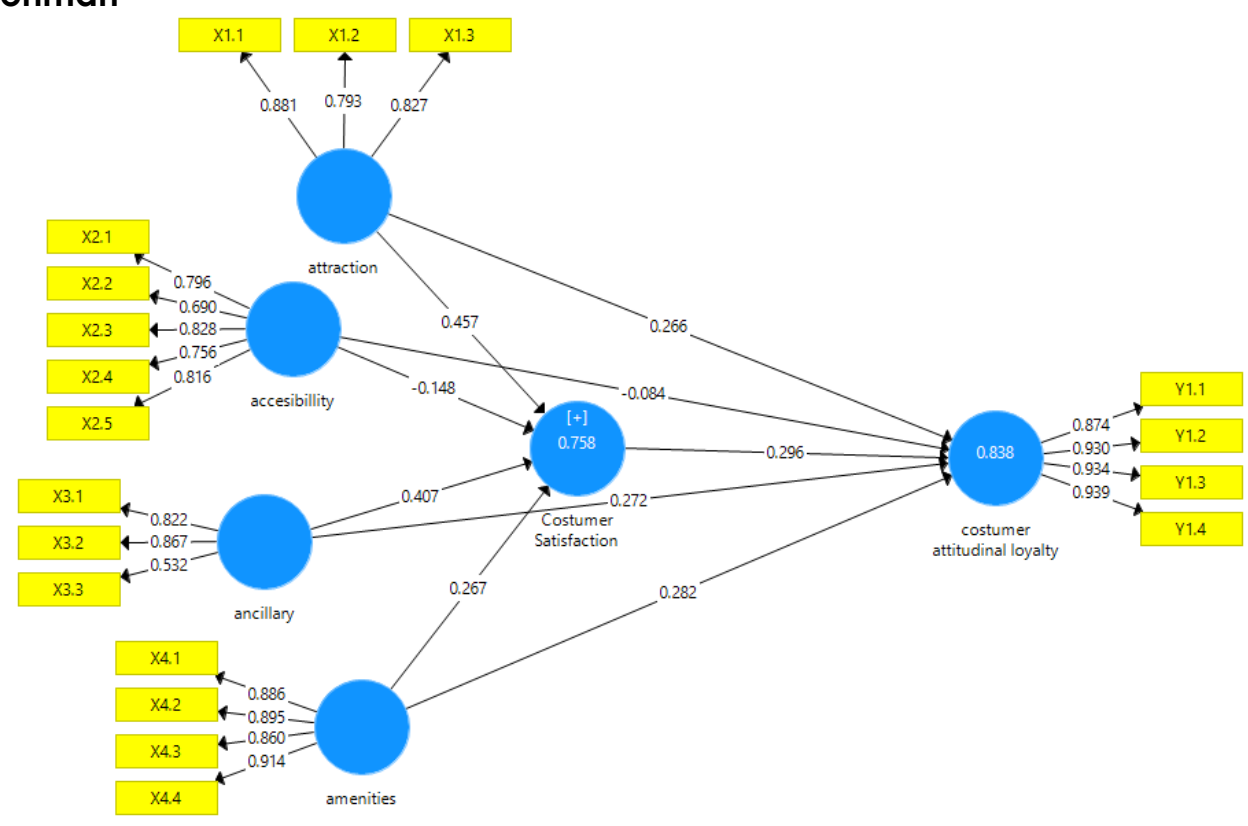

Figure 1.

Path Diagram 1

Source: primary data (2019)

Based on the path diagram, it can be seen that the ancillary item of X3.3 has a loading factor value below 0.6 ; therefore, the item is removed from the model.

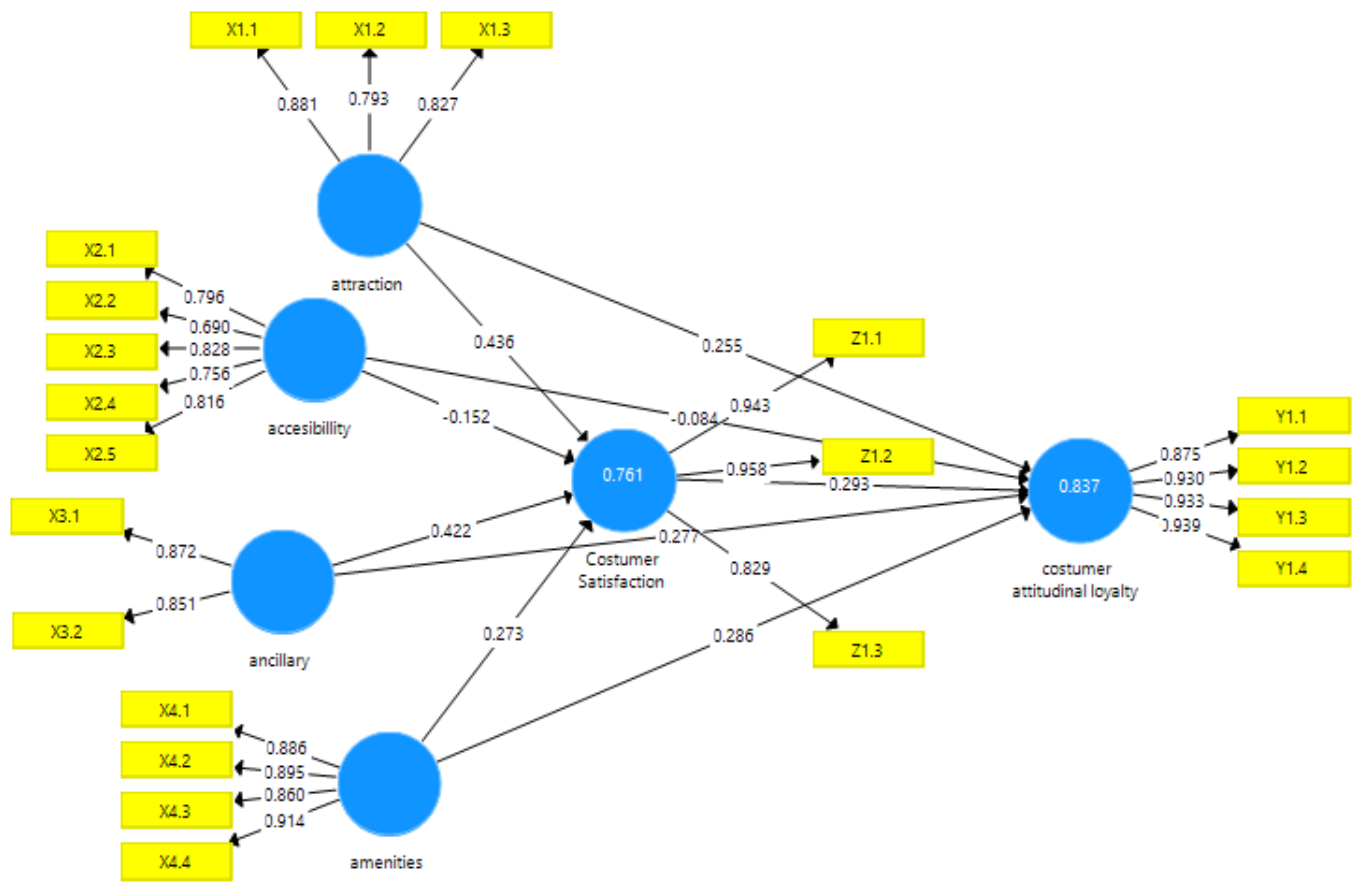

Figure 2.

Path Diagram 2

Source: primary data (2019) 
Outer Model analysis is Confirmatory Factor Analysis (CFA) that examines the validity and reliability of the latent constructs. To see whether a construct is valid or not, it considers convergent validity and discriminates validity of the construct. Convergent validity is assessed based on the loading factor (correlation between item score/component score and construct score) indicators that measure the construct. The Rule of Thumb used is Outer Loading > 0.6, Communality> 0.5 (Chin, 1995) in (Abdillah \& Jogiyanto, 2015). According to Ghozali and Latan (2014) the reflective measure is high if it correlates more than 0.70 with the construct that is to be measured for confirmatory research while for explanatory studies it is sufficient to have value range between 0.6 to 0.7 with the Cronbach alpha above 0.6.

Table 2.

Validity Test Result of the Instrument Using Loading Factor

\begin{tabular}{ccc}
\hline Item & Loading Factor & Conclusion \\
\hline X1.1 & 0.881 & Valid \\
X1.2 & 0.793 & Valid \\
X1.3 & 0.827 & Valid \\
X2.1 & 0.796 & Valid \\
X2.2. & 0.690 & Valid \\
X2.3. & 0.828 & Valid \\
X2.4. & 0.756 & Valid \\
X2.5 & 0.816 & Valid \\
X3.1 & 0.822 & Valid \\
X3.2. & 0.867 & Valid \\
X3.3 & 0.532 & Not Valid \\
X4.1 & 0.886 & Valid \\
X4.2 & 0.895 & Valid \\
X4.3 & 0.860 & Valid \\
X4.4 & 0.914 & Valid \\
Z1.1 & 0.943 & Valid \\
Z1.2 & 0.957 & Valid \\
Z1.3 & 0.831 & Valid \\
Y1.1 & 0.874 & Valid \\
Y1.2 & 0.930 & Valid \\
Y1.3 & 0.934 & Valid \\
Y1.4 & 0.939 & Valid \\
\hline
\end{tabular}

Based on Table 2 above, it can be seen that all indicators that measure each variable are valid so that that there is no problem of convergent validity on the model being tested. Parameters for testing discriminant validity can be assessed by looking at the calculation of the Cross Loading value. The results of discriminant validity measurement model using Cross Loading can be seen in Table 3.

Based on Cross Loading calculations in Table 3 above, it can be seen that overall indicators of Attraction, Accessibility, Amenities, Ancillary, Customer Satisfaction, and Customer Attitudinal Loyalty variables have loading factors greater than Cross Loading on other 


\section{Taufiq Ismail}

\section{Fatchur Rohman}

variables. Therefore, it can be concluded that each indicator can explain the variables that correspond to the indicators, so there is no discriminant validity problem in the tested model.

Reliability testing in PLS can use two methods, namely, the value of Cronbach's Alpha that must higher than 0.6 and the value of Composite Reliability that must be greater than 0.7. Composite Reliability and Cronbach Alpha are used as reliability indicators. According to Hussein (2015) data that has Composite Reliability greater than 0.7 has high reliability. Whereas, for Cronbach Alpha, the expected value is higher than 0.6 for all constructs and expected AVE > 0.5. The following are the results of the Composite Reliability and Cronbach Alpha analyzes that have been carried out.

Table 3.

Validity Test Result of the Instrument Using Cross Loading Factor

\begin{tabular}{llllllc}
\hline & $\begin{array}{c}\text { Visitor } \\
\text { Satisfaction }\end{array}$ & Accesibillity & Amenities & Ancillary & Attraction & $\begin{array}{c}\text { Visitor } \\
\text { Attitudinal } \\
\text { Loyalty }\end{array}$ \\
\hline X1.1 & 0.767 & 0.469 & 0.641 & 0.550 & 0.881 & 0.777 \\
X1.2 & 0.558 & 0.618 & 0.604 & 0.445 & 0.793 & 0.568 \\
X1.3 & 0.607 & 0.489 & 0.459 & 0.505 & 0.827 & 0.617 \\
X2.1 & 0.612 & 0.796 & 0.494 & 0.668 & 0.498 & 0.577 \\
X2.2 & 0.288 & 0.690 & 0.210 & 0.480 & 0.378 & 0.259 \\
X2.3 & 0.415 & 0.828 & 0.572 & 0.518 & 0.421 & 0.417 \\
X2.4 & 0.449 & 0.756 & 0.440 & 0.594 & 0.428 & 0.494 \\
X2.5 & 0.514 & 0.816 & 0.700 & 0.610 & 0.619 & 0.639 \\
X3.1 & 0.667 & 0.562 & 0.497 & 0.822 & 0.513 & 0.672 \\
X3.2 & 0.608 & 0.738 & 0.581 & 0.867 & 0.526 & 0.642 \\
X4.1 & 0.746 & 0.574 & 0.886 & 0.549 & 0.656 & 0.736 \\
X4.2 & 0.688 & 0.610 & 0.895 & 0.641 & 0.582 & 0.719 \\
X4.3 & 0.523 & 0.531 & 0.860 & 0.507 & 0.560 & 0.652 \\
X4.4 & 0.628 & 0.606 & 0.914 & 0.512 & 0.624 & 0.705 \\
Y1.1 & 0.748 & 0.691 & 0.653 & 0.750 & 0.743 & 0.875 \\
Y1.2 & 0.799 & 0.543 & 0.760 & 0.682 & 0.678 & 0.930 \\
Y1.3 & 0.773 & 0.553 & 0.735 & 0.691 & 0.702 & 0.933 \\
Y1.4 & 0.827 & 0.600 & 0.767 & 0.687 & 0.797 & 0.939 \\
Z1.1 & 0.943 & 0.609 & 0.744 & 0.716 & 0.699 & 0.806 \\
Z1.2 & 0.958 & 0.608 & 0.709 & 0.707 & 0.759 & 0.824 \\
Z1.3 & 0.829 & 0.448 & 0.545 & 0.597 & 0.683 & 0.707 \\
\hline
\end{tabular}

Based on Table 4, it can be seen that the value of Cronbach's Alpha from attraction variable is 0.783 , accessibility variable is 0.841 , ancillary variable is 0.654 , amenities variable is 0.912 , visitor satisfaction is 0.897 , and attitudinal loyalty is 0.939 . Also, it can be seen that the 
composite reliability value and overall Average Variance Extracted (AVE) value are above the minimum value. From the calculation of Chronbach's Alpha and Composite Reliability table, it can be seen that all indicators are reliable in measuring the latent variables.

Table 4.

Cronbach's Alpha and Composite Reliability

\begin{tabular}{llll}
\hline & $\begin{array}{l}\text { Cronbach } \\
\text { Alpha }\end{array}$ & $\begin{array}{l}\text { Composite } \\
\text { Reliability }\end{array}$ & AVE \\
\hline Attraction (X1) & 0.783 & 0.873 & 0.696 \\
Accessibility (X2) & 0.841 & 0.885 & 0.607 \\
Ancillary (X3) & 0.654 & 0.852 & 0.743 \\
Amenities (X4) & 0.912 & 0.938 & 0.790 \\
Visitor Satisfaction (Z) & 0.897 & 0.937 & 0.832 \\
Attitudinal Loyalty (Y) & 0.939 & 0.956 & 0.846 \\
\hline
\end{tabular}

Source: Primary data (2019)

\section{Inner Model Evaluation}

The structural model in PLS is evaluated using R square for the dependent construct, the path coefficient or t-values for each path to test significance between constructs in the structural model (Abdillah \& Jogiyanto, 2015). The higher the value of R-square, the better the prediction model of the proposed research model. Path coefficient value for $95 \%$ confidence level (Alpha 5\%), the t-table value for the Two-Tailed hypothesis is> 1.96 (Abdillah \& Jogiyanto, 2015).

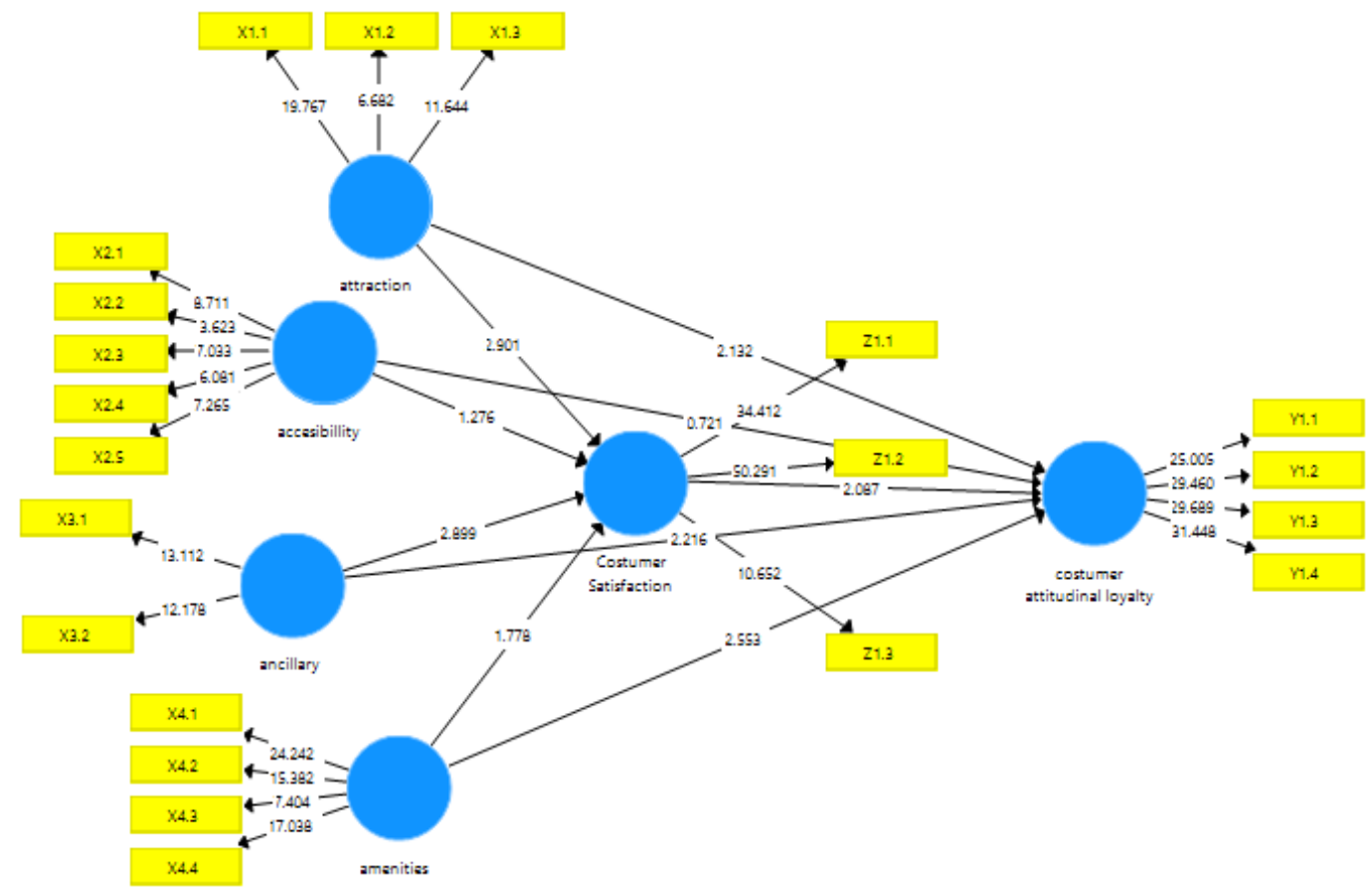

Figure 3.

Structural Model (Inner Model)

Source: Primary data (2019) 


\section{Taufiq Ismail}

\section{Fatchur Rohman}

Inner Model Evaluation can be seen from several indicators which include coefficient of determination (R-square), Predictive Relevance (Q-square) and Goodness Of Fit Index (GoF) (Hussein, 2015). The results of the structural models displayed by Smart PLS 3.0 in this study are as follows:

Table 5.

Structural Model Result

\begin{tabular}{lll}
\hline \multicolumn{1}{c}{ Variable } & R Square & Adjusted R-Square \\
\hline Customer Satisfaction & 0.761 & 0.734 \\
Customer Attitudinal Loyalty & 0.837 & 0.814 \\
\hline
\end{tabular}

Source: Primary data (2019)

Based on the calculation results in Table 5, it can be seen that the Adjusted R-square value of the visitor satisfaction variable is 0.734 , which means that visitor satisfaction is influenced by $4 \mathrm{~A}$ tourism components reaching $73.4 \%$ while the remaining $26.6 \%$ is the contribution of other variables not discussed in this study. Adjusted R-square results from visitor attitudinal loyalty is 0.814 meaning that visitor attitudinal loyalty is influenced by Attraction, Accessibility, Amenities and Ancillary by $81.4 \%$ while the rest $18.6 \%$ is influenced by other variables not discussed in this study.

Calculation of Goodness of Fit Model (GoF) can be used to determine the amount of contribution given by exogenous variables to endogenous variables. GoF values in PLS analysis can be calculated using Q-Square Predictive Relevance (Q-square). The following are the results of the calculation of the Goodness of Fit Model in this study:

$$
\begin{aligned}
& Q^{2}=1-\left(1-R 1^{2}\right)\left(1-R 2^{2}\right) \\
& Q^{2}=1-(1-0,734)(1-0,814) \\
& Q^{2}=0,95024
\end{aligned}
$$

Description:

$Q^{2}$ : Predictive Relevance

$R 1^{2}: R$-Sqyare of Customer Satisfaction

R2 2 : R-Square of Customer Attitudinal Loyalty

Based on the above calculation, the Q-Square Predictive Relevance value is 0.950 or $95 \%$. It demonstrates that the diversity of Customer Attitudinal Loyalty variables can be explained by the overall model by $95 \%$ or it can be interpreted that the contribution of Attraction, Accessibility, Amenities and Ancillary and Customer Satisfaction to Customer Attitudinal Loyalty as a whole is $95 \%$, while the rest is 5 The other\% is a variable contribution that was not discussed in this study. 


\section{Hypotheses Testing}

Hypothesis testing can be seen through path coefficients value. The value of path coefficients indicates how significant the hypothesis testing is. The hypothesis testing in this study uses $5 \%$ alpha which means if the t-statistic value is greater 1.96 or probability value at the level of significance equal to $5 \%$. The limit of 0.05 means that the probability of irregularities is only $5 \%$ and the remaining $95 \%$ is indicated to be able to accept the hypothesis. The Path Coefficients value can be seen through the t-statistic value that must be greater than the t-table which is 1.96 which means that there is an influence of the exogenous variables on the endogenous variables on each predetermined hypothesis. Tstatistic value greater than 1.96 or probability value $\leq$ Level of Significance ( $a=5 \%$ ), thus it can be concluded that the hypothesis is accepted; in other words, there is a significant influence between the tested variables.

Table 6.

Path Coeffients

\begin{tabular}{|c|c|c|c|c|c|c|c|}
\hline \multicolumn{3}{|l|}{ Variables } & \multirow{2}{*}{$\begin{array}{c}\begin{array}{c}\text { Original } \\
\text { Sample }\end{array} \\
0.436\end{array}$} & \multirow{2}{*}{$\begin{array}{c}\begin{array}{l}\text { Sample } \\
\text { Mean (M) }\end{array} \\
0.400\end{array}$} & \multirow{2}{*}{$\begin{array}{c}\begin{array}{c}\text { Standard } \\
\text { Deviation }\end{array} \\
0.150\end{array}$} & \multirow{2}{*}{$\frac{\text { t-statistics }}{2.901}$} & \multirow{2}{*}{$\begin{array}{l}\begin{array}{l}\text { p- } \\
\text { values }\end{array} \\
0.004\end{array}$} \\
\hline $\begin{array}{l}\text { Hl: Attraction } \\
\text { satisfaction }\end{array}$ & $->$ & visitor & & & & & \\
\hline $\begin{array}{l}\text { H2: Accesibillity } \\
\text { satisfaction }\end{array}$ & $->$ & visitor & -0.152 & -0.124 & 0.119 & 1.276 & 0.203 \\
\hline $\begin{array}{l}\text { H3: Ancillary } \\
\text { Satisfaction }\end{array}$ & $->$ & visitor & 0.422 & 0.420 & 0.145 & 2.899 & 0.004 \\
\hline $\begin{array}{l}\text { H4: Amenities } \\
\text { satisfaction }\end{array}$ & $->$ & visitor & 0.273 & 0.285 & 0.153 & 1.778 & 0.076 \\
\hline $\begin{array}{l}\text { H5: Attraction } \\
\text { attitudinal loyalty }\end{array}$ & $->$ & visitor & 0.255 & 0.257 & 0.119 & 2.132 & 0.033 \\
\hline $\begin{array}{l}\text { H6: Accesibillity } \\
\text { attitudinal loyalty }\end{array}$ & $->$ & visitor & -0.084 & -0.050 & 0.116 & 0.721 & 0.471 \\
\hline $\begin{array}{l}\text { H7:Ancillary ->visito } \\
\text { attitudinal loyalty }\end{array}$ & or cus & stomer & 0.277 & 0.276 & 0.125 & 2.216 & 0.027 \\
\hline $\begin{array}{l}\text { H8: Amenities } \\
\text { attitudinal loyalty }\end{array}$ & $->$ & visitor & 0.286 & 0.290 & 0.112 & 2.553 & 0.011 \\
\hline $\begin{array}{l}\text { H9: Visitor Satisfacti } \\
\text { attitudinal loyalty }\end{array}$ & ion - & visitor & 0.293 & 0.274 & 0.140 & 2.087 & 0.037 \\
\hline
\end{tabular}

Hypothesis 1 Attraction has a significant influence on visitor satisfaction of Gill Ketapang. The t-statistic relationship between attraction and visitor satisfaction is 2.901 with a probability of 0.004 . The test results indicate that t-statistic greater than 1.96 and probability value is less than its level of significance ( $a=5 \%$ ). This shows that there is a significant positive effect of attraction on visitor satisfaction; thus, Hypothesis 1 is accepted.

Hypothesis 2 Accessibility does not have significant effect on visitor satisfaction of Probolinggo Gili Ketapang. The t-statistic between accessibility and visitor satisfaction is 1.276 with a probability of 0.203 . The test results indicate that t-statistic is less than 1.96 and 


\section{Taufiq Ismail}

\section{Fatchur Rohman}

probability value greater than its level of significance $(a=5 \%)$. This shows that there is no significant positive influence of accessibility on visitor satisfaction. Thus Hypothesis 2 is rejected.

Hypothesis 3 Ancillary has a significant influence on visitor satisfaction of Gili Ketapang. The †statistic between attraction and visitor satisfaction is 2.889 with a probability of 0.04 . The test results show t-statistic is greater than 1.96 and probability value $\leq$ Level of Significance $(a=$ $5 \%)$. This shows that there is a significant positive effect between ancillary and visitor satisfaction. Thus Hypothesis 3 is accepted.

Hypothesis 4 Amenities does not have a significant effect on visitor satisfaction of Gili Ketapang Island. The t-statistic between attraction and visitor satisfaction is 1.778 with a probability of 0.76 . The test results indicate that t-statistic is less than 1.96 and probability value is greater than its level of significance $(a=5 \%)$. This shows that there is no significant positive effect of attraction on visitor satisfaction. Thus Hypothesis 4 is rejected.

Hypothesis 5 Attraction has a significant influence on visitor attitudinal loyalty of Gili Ketapang. The t-statistic between attraction and visitor attitudinal loyalty is 2.132 with a probability of 0.033 . The result indicates that the t-statistic $\geq 1.96$ with probability value $\leq$ its level of Significance ( $a=5 \%$ ). This shows that there is a significant positive effect of attraction on visitor attitudinal loyalty; thus, hypothesis 5 is accepted.

Hypothesis 6 Accessibility does not have significant influence on visitor attitudinal loyalty of Gili Ketapang Island. The t-statistic between accessibility and visitor attitudinal loyalty is 0.712 with a probability of 0.471 . The test results show that t-statistic less than 1.96 and probability value is greater than its level of significance $(a=5 \%)$. This shows that there is no significant positive effect of accessibility on visitor attitudinal loyalty. Thus Hypothesis 6 is rejected.

Hypothesis 7 Ancillary has a significant effect on visitor attitudinal loyalty of Gili Ketapang. The t-statistic between ancillary to visitor attitudinal loyaly is 2,216 with a probability of 0.027 . The test results show that t-statistic $\geq 1.96$ and probability value $\leq$ Level of Significance $(a=$ $5 \%)$. This shows that there is a significant positive effect of ancillary on visitor attitudinal loyalty. Thus Hypothesis 7 is accepted.

Hypothesis 8 Amenities have a significant influence on visitor attitudinal loyalty of Gili Ketapang. The t-statistic between attraction to visitor attitudinal loyalty is 2.553 with a probability of 0.11 The test results show that t-statistic $\geq 1.96$ and probability value $\leq$ Level of 
Significance $(a=5 \%)$. This shows that there is a significant positive effect of amenities on visitor attitudinal loyalty meaning that Hypothesis 8 is accepted.

Hypothesis 9 Visitor Satisfaction has a significant influence on visitor attitudinal loyalty of Gili Ketapang. The t-statistic of visitor satisfaction on visitor attitudinal loyalty is 2.087 with a probability of 0.037 . The the t-statistic is greater than 1.96 and the probability value is $\leq$ Level of Significance $(a=5 \%)$. This shows that there is a significant positive effect between visitor satisfaction and visitor attitudinal loyalty. Thus Hypothesis 9 is accepted.

Table 7.

Sobel Test for Mediating Effect

\begin{tabular}{clccc}
\hline Hypotesis & \multicolumn{1}{c}{ Variables } & t-statistic & p-value & Conclusion \\
\hline H10a & $\begin{array}{l}\text { Attraction -> attitudinal loyalty } \\
\text { through visitor satisfaction }\end{array}$ & 11.80683757 & 0.000 & Significant \\
H10b & $\begin{array}{l}\text { Accessibility -> attitudinal loyalty } \\
\text { through visitor satisfaction }\end{array}$ & 8.70472403 & 0.000 & Significant \\
H10c & $\begin{array}{l}\text { Amenities -> attitudinal loyalty } \\
\text { through visitor satisfaction }\end{array}$ & 11.9508255 & 0.000 & Significant \\
H10d & $\begin{array}{l}\text { Ancillary-> attitudinal loyalty } \\
\text { through visitor satisfaction }\end{array}$ & 9.16510259 & 0.000 & Significant \\
\hline
\end{tabular}

Hypothesis 10 Visitor satisfaction has significant mediation role from all of the 4A tourism components on visitor attitudinal loyalty. The results indicates that the mediation role of visitor satisfaction is important to signify the effect of attraction, accessibility, amenities, and ancillary on visitor attitudinal loyalty.

\section{CONCLUSION}

This research was conducted to find out whether there was an influence among attraction, accessibility, amenities and ancillary variables on customer attitudinal loyalty mediated by visitor satisfaction when visiting Gili Ketapang beach. This research amplifies that the among the four components of tourism only attraction and ancillary that influence visitor satisfaction significantly which confirms the importance of attraction on the proposed theoretical perspectives from some former researchers (Andrianto \& Sugiyama, 2016; Leask, 2016) whereas accessibility and amenity do not have significant influence on visitor satisfaction which do not support the perspective of Jamaludin and Kadir (2017). Dewi et al. (2017) findings are confirmed in this research as it is only accessibility among the other three tourism components that does not have any significant role on visitor attitudinal loyalty. Accessibility does not have significant influence both on visitor satisfaction and attitudinal loyalty. Yet, the mediation role of satisfaction on attitudinal loyalty of the visitors demonstrate positive and significant role which justifies the result of Hussein at al. (2015). 


\section{Taufiq Ismail}

\section{Fatchur Rohman}

Based on the results of the study, the theoretical implications in this study provides a reference to the results of former research related to the application of perception evaluation on satisfaction for tourism destinations consisting of attraction, accessibility, amenities and ancillary, as well as its influence on customer attitudinal loyalty through satisfaction particularly for nature-based attractions. Therefore, the next research can consider exploring more on the visitor's decisions in choosing tourism destination that have an impact on visitor loyalty like visitor trust or other pivotal variable. Next, visitor satisfaction in this research is a mediator between tourism components and visitor attitudinal loyalty. This finding can be the foundation to develop more comprehensive model for decision making in choosing tourism destinations for the visitor perspective as well as feedback for tourism management organization.

In addition, this research also provides some implications for managers of Gili Ketapang beach. Frist, the management of Gili Ketapang beach must be able to improve its infrastructure and environmental management. The existence of adequate infrastructure will affect the convenience of visitors. For instance, adding more capacity of prayer room and the number of restaurants that serve better food service are good options. Next, Gili Ketapang beach may add educational recreation or leisure, especially with regard to environmental sustainability and coral reefs issue.

Flnally, the results of this study can be used as a source of data on how to build long-term relationships with visitors. Gili Ketapang beach must meet the needs and expectations of visitors so that visitors feel satisfied and retained to revisit. Visitor satisfaction as the mediation on the attitudinal loyalty has the implication from consumer knowledge about Gili Ketapang beach. Because visitor satisfaction is related to a number of cognitions, feelings, conceptions, knowledge, imagination, emotional thoughts, ideas, and impressions held by visitors that form a picture of the attraction.

\section{REFERENCES}

Abdillah, W., and Jogiyanto, H. M. 2015. PLS (Partial Least Square) Alternatif Structural Equation Modeling (SEM) dalam Penelitian Bisnis. Andi: Yogyakarta.

Andrianto, T., and Sugiama, A. G. 2016. The Analysis of Potential 4A's Tourism Component in the Selasari Rural Tourism, Pangandaran, West Java. Asia Tourism Forum 2016 - The $12^{\text {th }}$ Biennial Conference of Hospitality and Tourism Industry in Asia (ATF-16). Atlantic Press.

Chen, P. T., and Hu, H. H. 2010. The Effect of Relational Benefits on Perceived Value in Relation to Customer Loyalty: An Empirical Study in The Australian Coffee Outlets Industry. International Journal of Hospitality Management 29(3): 405-412. 


\section{Jurnal Manajemen Teori dan Terapan \\ Tahun 12. No. 2, Agustus 2019}

Connell, J., Page, S. J., and Meyer, D. 2014. Visitor Attraction and Events: Responding to Seasonality. Tourism Management 46: $283-298$.

Dewi, N. I. K., Astawa, I. P., Siwantara, I. W., and Bagus, I. G. A. 2017. Strategy Development: Case Study on Two Cultural Villages in Bali. Journal of Advances in Humanities and Social Sciences 3(6): 293-302.

Etemad-Sajadi, R. and Rizzuto, D. 2013. The Antecedents of Consumer Satisfaction and Loyalty in Fast Food Industry: A Cross-National Comparison between Chinese and Swiss Consumers. International Journal of Quality and Reliability Management 30(7): 780-798.

Ghozali, I., and Hengky, L. 2014. Partial Least Squares: Konsep, Teknik dan Aplikasi Menggunakan Program Smart PLS3.0 edisi kedua. Universitas Diponegoro, Semarang.

Goeldner, C. R., and Ritchie, J. R. B. 2009. Tourism Principles, Practices, Philosophies 9th Editions. Canada: John Wiley \& Sons.

Hiransomboon, K. 2017. Using convenience store service of foreign backpacker tourists in Bangkok, Thailand. International Journal of Business and Economic Affairs 2(1): 1-7. DOI: 10.24088/ijbea-2017-21001.

Hussein, A. S. 2015. Penelitian bisnis dan manajemen menggunakan partial least squares (PLS) dengan smart PLS 3.0. Modul ajar jurusan manajemen fakultas ekonomi dan bisnis unversitas Brawijaya.

Hussein, A. S., Ismail, T. and Hapsari, R. D. V. 2015. The Formation of Brand Loyalty in Indonesian Restaurant Industry. European Journal of Tourism, Hospitality, and Recreation 6: 67-98.

Jamaludin, M., and Kadir, S. A. 2014. Accessibility in buildings of tourist attraction: A case studies comparison. Procedia - Social and Behavioral Sciences 35: 97e 104.

Jensen, J. M. 2011. Customer loyalty on the grocery product market: an empirical application of Dick and Basu's framework. Journal of Consumer Marketing 28(5): 333343.

Kotler, P., and Kevin L. K. 2016. Marketing Management, 15th Edition. Pearson Education Inc.

Leask, A. 2016. Visitor Attraction Management: A Critical Review of Research 2009-2014. Tourism Management 57: 334-361.

Martin, W. C., Ponder, N., and Lueg, J. E. 2009. Price Fairness Perception and Customer Loyalty in Retail Context. Journal of Business Research 62(6): 588-593.

McMullan, R. and Gilmore, A. 2008. Customer Loyalty: An Empirical Study. European Journal of Marketing 42(9/10): 1084-1094.

Orel, F. D., and Kara, A. 2014. Supermarket Self-Checkout Service Quality, Customer Satisfaction, and Loyalty: Empirical Evidence from an Emerging Market. Journal of Retailing and Consumer Services 21 (2): 118-129. 


\section{Taufiq Ismail}

\section{Fatchur Rohman}

Solomon, L. R. 2017. Consumer Behaviour: Buying, Having, and Being. 12 $2^{\text {th }}$ Edition (Global Edition). Pearson Education Ltd.

Song, H., Dwyer, L., Li, G., and Cao, Z. 2012. Tourism Economics Research: a Review and Assessment. Annals of Tourism Research 39(3): 1653-1682.

Sugiama, A. G. 2013. Manajemen Aset Pariwisata: Pelayanan Berkualitas Agar Wisatawan Puas dan Loyal. Guardaya Intimarta. Bandung.

Suhartanto, D., Clemes, M., and Dean, D. 2013. Analyzing the Complex and Dynamic Nature of Brand Loyalty in the Hotel Industry. Tourism Review Internasional 17(1): 47-61.

Tugcu, C. T. 2014. Tourism and Economic Growth Nexus Revisited: a Panel Causality Analysis for the case of the Mediterranean Region. Tourism Management 42(3): 207-212.

Webster, C., and Ivanov, S. 2014. Transforming Competitiveness into Economic Benefits: Does Tourism Stimulate Economic Growth in More Competitive Destinations? Tourism Management 40(1): 137-140.

Wu C. 2016. Destination Loyalty Modelling of the Global Tourism. Journal of Business Research 69(2016): 2213-2219.

Zeithaml, V., Wilson, A., Bitner, M. J., and Gremler, D. D. 2016. Services Marketing: Integrating Customer Focus Across the Firm. McGraw-Hill Education. 